\title{
Estimation of antioxidant and hepatoprotective activity of Sphaeranthus indicus Linn leaves extract
}

\author{
Mohammad Hashim Mansoori ${ }^{1,2}$, M.K. Gupta ${ }^{2}$, Vijay Mishra ${ }^{3 *}$, Nishika Yadav ${ }^{3}$, \\ Manish Vyas ${ }^{3}$
}

${ }^{1}$ Department of Pharmacy, Adina Institute of Pharmaceutical Sciences, Sagar, Madhya Pradesh, India, ${ }^{2}$ Department of Pharmacy, Oriental University, Indore, Madhya Pradesh, India, ${ }^{3}$ School of Pharmaceutical Sciences, Lovely Professional University, Phagwara,Punjab, India

Abstract

Aim: The present study aimed to investigate the antioxidant and hepatoprotective activity of an extract of Sphaeranthus indicus Linn leaves against the carbon tetrachloride $\left(\mathrm{CCl}_{4}\right)$-induced hepatotoxicity using in vitro and in vivo models of liver injury. Materials and Methods: The coarsely powdered leaves of $S$. indicus Linn were successfully extracted with petroleum ether extract (SIPEE), chloroform extract (SICHE), ethyl acetate extract (SIEAE), ethanolic extract (SIEE), and aqueous extract (SIAQE). The total tannin content, total phenolic content, and total flavonoids content were evaluated. Extracts were administered to evaluate in vitro human live hepatoma cell line study and in vivo hepatoprotective activity against $\mathrm{CCl}_{4}$ intoxicated mice. Results: Different extracts of SI presented reducing power in the order of Vitamin $\mathrm{C}>$ SIEE $>$ SIEAE $>$ SICHE $>$ SIAQE $>$ SIPEE. At the concentration $200 \mu \mathrm{g} / \mathrm{mL}$, SIEE showed $50.4 \%$ 2,2-diphenyl-1-picrylhydrazyl scavenging property, $57.1 \%$ hydroxyl radical ${ }^{\circ}$ scavenging activity, $46.1 \%$ nitric oxide ${ }^{\circ}\left(\mathrm{NO}^{\circ}\right)$ radical scavenging property, and $73.2 \%$ superoxide radical scavenging action. The treatment with SIEE prevented the hepatic malondialdehyde level by $22.22,26.67$, and $58.89 \%$ with the doses of 100,200 , and $400 \mathrm{mg} / \mathrm{kg}$, respectively. Conclusion: This study suggested that the presence of flavonoids in $S$. indicus Linn leaves exhibiting marked antioxidant and hepatoprotective activities.

Key words: Antioxidant, flavonoids, free radicals, hepatoprotective effect, Sphaeranthus indicus

\section{INTRODUCTION}

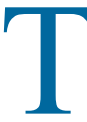
he liver plays a pivotal role in metabolism but at the same time exposed to an environmental pollutant, chemotherapeutic agent, and xenobiotics continuously results in the rise of free radicals such as reactive oxygen species/ reactive nitrogen species. Hepatotoxicity related to many drugs or its transformation to chemically reactive metabolites that may be influenced by therapeutic, physiological, or nutritional factors interfering with drug elimination or formation of a reactive metabolite or their detoxification. It is caused by drug accumulation or may be due to metabolic inhibition by other drugs or liver damage.

Sphaeranthus indicus plant is employed indigenously for the management of insanity, hemicrania, epilepsy, tuberculosis (TB), anemia, bronchitis, elephantiasis, leukoderma, jaundice, hemicranias, diabetes, leprosy, pectoralgia, fever, cough, hernia, gastropathy, helminthiasis, hemorrhoids, skin diseases, dyspepsia and mental disorders as well as also used as a nerve tonic, laxative, digestive, and anthelmintic. ${ }^{[1,2]}$ The present study aimed to execute the biological active constituents existing in this plant, responsible for the antioxidant and hepatoprotective activity as well as pharmacological evaluation of the protective and curative effect of different extracts of $S$. indicus Linn leaves in contradiction of oxidative stress persuades liver damage in vivo and in vitro.

\section{Address for correspondence:}

Dr. Vijay Mishra, School of Pharmaceutical Sciences, Lovely Professional University, Phagwara, Punjab, India - 144 411. E-mail: vijaymishra2@gmail.com

Received: $26-10-2018$

Revised: $15-11-2018$

Accepted: $25-11-2018$ 


\section{MATERIALS AND METHODS}

\section{Chemicals and Reagents}

Vitamin C, gallic acid, sodium nitroprusside, nitro blue tetrazolium (NBT), hydroxylamine hydrochloride, streptomycin, and penicillin were purchased from SigmaAldrich, Mumbai. The carbon tetrachloride $\left(\mathrm{CCl}_{4}\right)$ and Folin-Ciocalteu reagent were purchased from SD Fines Chemicals Pvt. Ltd., Mumbai. 2,2-diphenyl-1-picrylhydrazyl (DPPH), Dulbecco's Modified Eagle's Medium (DMEM), trypsin, trypan blue, dimethyl sulfoxide (DMSO), and ethylenediaminetetraacetic acid (EDTA) were purchased from Bioworld, Mumbai and HiMedia, Bengaluru, respectively. The silymarin was received from Micro Lab, Baddi as gift sample. All other solvents and chemicals of the analytical grade used in this study were obtained from the local supplier.

\section{Collection and Authentication of Plant Material}

The fresh leaves of S. indicus Linn. collected from the plants grown in Sagar, Madhya Pradesh, India, were validated by Dr. P. K. Tiwari, Department of Botany, Dr. H. S. Gour Central University, Sagar Madhya Pradesh, India. The specimen of S. indicus Linn with Bot/H/04/87/11 Herbarium numbers, respectively, was deposited in the botany department of university for upcoming reference. The plant leaves were initially washed by water followed by drying in the shade and then coarsely powdered from the grinder.

\section{Experimental Animals}

For the present investigation, Swiss albino rats of either sex with weight of 180-240 g were acquired from the College of Veterinary Sciences and Animal Husbandry, Mhow, Madhya Pradesh, India. The animals were made familiarize for the duration of 2 weeks from the beginning of the experiment and housed in standard laboratory surroundings (that is, $45-65 \%$ of relative humidity, $25 \pm 2^{\circ} \mathrm{C}$ of temperature, and $12 \mathrm{~h}$ dark and $12 \mathrm{~h}$ light cycle). Animals were fed by standard laboratory animal feed and water ad libitum during the experiment. The protocol for experimental work on animals was approved by the Institution Animal Ethical Committee (IAECNo.1546/PO/E/S/11/CPCSEA).

\section{Cell Line Culture}

The human live hepatoma cells (HepG2) are obtained from the National Center for Cell Science, Pune, India. HepG2 cells $\left(1 \times 10^{5}\right.$ cells/T25 flask) sowed and cultivated in DMEM containing penicillin (100 IU $/ \mathrm{mL})$, streptomycin $(0.1 \mu \mathrm{g} / \mathrm{mL})$, and fetal bovine serum $(10 \% \mathrm{w} / \mathrm{v})(10 \% \mathrm{w} / \mathrm{v})$, then incubated in $\mathrm{CO}_{2}$ atmosphere at $37 \pm 2^{\circ} \mathrm{C}$ and humidified $5 \%$ intended for $24 \mathrm{~h}$ for $>80 \%$ convergence. Cells passaged by sub-confluent culture trypsinization by Trypsin Phosphate Versene Glucose solution consisting trypsin $(0.2 \% \mathrm{w} / \mathrm{v})$, glucose $(0.05 \% \mathrm{w} / \mathrm{v})$, and EDTA $(0.02 \% \mathrm{w} / \mathrm{v})$ in saline phosphate buffer.

\section{Extraction of Plant Materials}

In a Soxhlet apparatus, the powdered leaves $(500 \mathrm{~g})$ were closely packed, and successive extraction was carried out first with petroleum ether at $40-60^{\circ} \mathrm{C}$ and then with chloroform, followed by ethyl acetate and at last ethanol. Maceration for $48 \mathrm{~h}$ in distilled water was carried out with the left-over marc and then filtered. From thimble of the apparatus, some drops of extractive were collected and evaporated. The absence of residue confirmed completion of the extraction process. This ensures that no solvents remain; the marc was dried in air before using the next solvent for extraction. Rotary evaporator set at $40 \pm 2{ }^{\circ} \mathrm{C}$ was used for vacuum drying the collected filtrates. The different SI extracts used in the present study are - chloroform extract (SICHE), ethyl acetate extract (SIEAE), petroleum ether extract (SIPEE), aqueous extract (SIAQE), and ethanolic extract (SIEE).

\section{Determination of Phytoconstituents}

The results obtained by phytochemical screening of SI extracts represented that SIEE consists of glycosides, carbohydrates, sterols, and flavonoids; SIEAE consists of tannins, and flavonoids; and SICHE contains triterpenoids and phytosterols although SIAQE consists of carbohydrates, glycosides, and alkaloids. Amino acid and proteins were resulted as absent in entire extracts whereas fats and fixed oil were present merely in SIPEE of SI extract. The reaction between aluminum trichloride and flavonoids produced a red colored compound. Their intensity was measured to determine the total flavonoid content (TFC). ${ }^{[3]}$ Precipitation of tannins using gelatin was carried out for the identification of total tannin content (TTC), while the Folin-Ciocalteu method was utilized for identification of total phenolic content (TPC). ${ }^{[4]}$

\section{Determination of Antioxidant Activity}

- Reducing power assay

Antioxidants are potent reductants. Their presence would result in $\mathrm{Fe}^{3+}-\mathrm{Fe}^{2+}$ reduction due to electron donation. This serves as an indication for antioxidant activity. Chromophore absorbance measured at a wavelength of $700 \mathrm{~nm}$ to determine the reducing power of extracts. ${ }^{[5]}$

- DPPH radical scavenging assay

This scavenging assay is used to understand the antiradical activity of extracts and to determine the presence of flavonoids and phenolics. ${ }^{[6]}$ The reaction between $\mathrm{DPPH}^{\circ}$ radical and proton donor leads to the formation of the yellow colored complex. The intensity of this color is used to determine the $\mathrm{DPPH}^{\circ}$ radical 
scavenging activity. ${ }^{[3]}$ The $\mathrm{DPPH}^{\circ}$ radical scavenging activity was determined by the following equation:

Scavenging activity $(\%)=\left(\frac{A_{o}-A_{t}}{A_{o}}\right) \times 100$

Where, $\mathrm{A}_{0}=$ Control absorbance, $\mathrm{A}_{\mathrm{t}}=$ Sample absorbance

- Hydroxyl radical $\left(\mathrm{OH}^{\circ}\right)$ scavenging assay

$\mathrm{OH}^{\circ}$ can be produced using Fenton reaction in the occurrence of the reduced transition metals $\left(\mathrm{Fe}^{2+}\right)$ and $\mathrm{H}_{2} \mathrm{O}_{2}$, known as the best reactive system amid all dioxygen reduced forms and thought to begin in vivo the cell injury. ${ }^{[7]}$

- $\quad$ Nitric oxide ${ }^{\circ}\left(\mathrm{NO}^{\circ}\right)$ radical scavenging assay

Griess reagent has the ability to inhibit $\mathrm{NO}^{\circ}$ radical. The radical generated from sodium nitroprusside solution in the phosphate buffer saline. The ability of Griess reagent to inhibit $\mathrm{NO}^{\circ}$ radical was analyzed at $546 \mathrm{~nm} .{ }^{[8]}$ The $\mathrm{NO}^{\circ}$ radical scavenging activity was determined by Eq. 1 .

- $\quad$ Superoxide radical scavenging assay

NBT reagent method was used for the estimation of superoxide $\left(\mathrm{O}_{2}^{-}\right)$radical scavenging action of extracts. In the presence of NBT, auto-oxidation of hydroxylamine hydrochloride resulted in the formation of $\mathrm{O}_{2}-$. The radical was reduced to nitrite. In the presence of EDTA, the nitrite ion produces a colored complex, the intensity measured at $560 \mathrm{~nm} \cdot{ }^{[9]}$ The $\mathrm{O}_{2}$ - radical scavenging ability was determined by Eq.1.

- Inhibition of lipid peroxidation (LPO) in rat liver homogenate

When malondialdehyde, the secondary end product of $\mathrm{Fe}^{+2}$-induced polyunsaturated fatty acids oxidation, reacts from two molecules of 2-thiobarbituric acid, it leads to the formation of pinkish-red colored chromogen. The intensity of this chromogen is measured to determine LPO inhibition activity of the extracts. A decrease in LPO is indicated by a decrease in absorbance. ${ }^{[10,11]}$ The LPO percent inhibition was calculated by Eq.1.

\section{Determination of in vitro Hepatoprotective Effect}

For determination of in vitro hepatoprotective effect on HepG2 cell line against $\mathrm{CCl}_{4}$-induced damage, $\mathrm{HepG} 2$ cells $\left(3 \times 10^{6}\right.$ cells/well) were sustained in various groups in 96 well culture plates; then media were detached and the cells were treated by solutions of silymarin, $\mathrm{CCl}_{4}(1 \% \mathrm{v} / \mathrm{v})$ and numerous SI extracts, formed in serum-free DMEM comprising $0.1 \% v / v$ of DMSO at various selected concentrations, respectively. Group I (Normal controlled group) was treated by $100 \mu \mathrm{L}$ serum-free DMEM comprising DMSO $(0.1 \% v / v)$. Group II (Toxicant controlled) was treated by $100 \mu \mathrm{L}$ as of $\mathrm{CCl}_{4}(1 \% v / v)$ formed in the serum-free DMEM comprising DMSO of $0.1 \% v / v$. Group III (Silymarin treated) was treated by $100 \mu \mathrm{L}$ as of $\mathrm{CCl}_{4}(1 \% v / v)$ and $100 \mu \mathrm{L}$ of silymarin in different concentration $(50,100,150,200$, and $250 \mu \mathrm{g} / \mathrm{mL})$.
Groups IV-VI was treated by $100 \mu \mathrm{L}$ as $\mathrm{CCl}_{4}(1 \% v / v)$ and $100 \mu \mathrm{L}$ of SIPEE in different concentration $(50,100,150$, 200 , and $250 \mu \mathrm{g} / \mathrm{mL}$ ). Groups VII-IX was treated by $100 \mu \mathrm{L}$ as of $\mathrm{CCl}_{4}(1 \% v / v)$ and SICHE in several concentration (50, $100,150,200$, and $250 \mu \mathrm{g} / \mathrm{mL}$ ). Groups X-XII was treated by $100 \mu \mathrm{L}$ as of $\mathrm{CCl}_{4}(1 \% v / v)$ and $100 \mu \mathrm{L}$ of SIEAE in different concentration $(50,100,150,200$, and $250 \mu \mathrm{g} / \mathrm{mL})$. Groups XIII-XV was treated by $100 \mu \mathrm{L}$ as of $\mathrm{CCl}_{4}(1 \% \nu / v)$ and $100 \mu \mathrm{L}$ of SIEE in numerous concentration $(50,100$, 150,200 , and $250 \mu \mathrm{g} / \mathrm{mL}$ ). Groups XVI-XVIII was treated by $100 \mu \mathrm{L}$ as of $\mathrm{CCl}_{4}(1 \% v / v)$ and $100 \mu \mathrm{L}$ of SIAQE in different concentration $(50,100,150,200$, and $250 \mu \mathrm{g} / \mathrm{mL})$. Absorbance from untreated cells was taken as $100 \%$ survival of cell and percentage relative cell viability was calculated by Eq.2.

$\%$ Cell viability $=\frac{\mathrm{Abs}_{\text {control }}-\mathrm{Abs}_{\text {sample }}}{\mathrm{Abs}_{\text {control }}} \times 100$

Where $\mathrm{Abs}_{\text {control }}$ and $\mathrm{Abs}_{\text {sample }}$ are absorbances of control and test sample, respectively. Extracts $\mathrm{IC}_{50}$ values were evaluated to select active extract of SI.

\section{Determination of in vivo Hepatoprotective Effects}

In this study, the protective action of SI extracts alongside alcohol-induced hepatic damage was determined; only those extracts which showed significant antioxidant activity as well as in vitro hepatoprotective activity against $\mathrm{CCl}_{4}-$ induced hepatic damage in HepG2 cell line, using ethanol as a toxicant. Prophylactic and curative effects of same plants extracts were determined using $\mathrm{CCl}_{4}$ as hepatotoxin. Acute oral toxicity was implemented permitting the Organization for Economic Co-operation and Development guideline No. 423. ${ }^{[12]}$ The female rats were fasted for a night, retrieving water ad libitum utilized in the study. Plant extract directed orally $300 \mathrm{mg} / \mathrm{kg}$ of dose to body weight and animals observed for death or slightly unusual actions for starting $24 \mathrm{~h}$ and afterward 14 days. This process repeated at $2000 \mathrm{mg} / \mathrm{kg}$ dose of the body. Additional responses of neurology, responses of behavior, as well as responses autonomic were detected.

\section{Prophylactic and Curative Studies}

Swiss albino rats of 180-250 g were separated into different groups, every group contains six animals $(\mathrm{n}=6)$. Group I (Normal control) received Tween $80(1 \mathrm{~mL} / \mathrm{kg}$ b.w.) vehicle. In Group II (Toxicant control), $\mathrm{CCl}_{4}$ received olive oil (1:1) at $0.5 \mathrm{~mL} / \mathrm{kg} b$.w. dose. Group III (Silymarin treated), $\mathrm{CCl}_{4}$ in olive oil with silymarin of $100 \mathrm{mg} / \mathrm{kg} b . w$. (1:1) were received at dose of $0.5 \mathrm{~mL} / \mathrm{kg} b . w$. Groups IV-VI (SIEAE treated), at the dose of 100,200 , and $400 \mathrm{mg} / \mathrm{kg} \mathrm{b.w}$. with $\mathrm{CCl}_{4}$ in olive oil (1:1) at a dose of $0.5 \mathrm{~mL} / \mathrm{kg} \mathrm{b.w.}$, respectively, received SIEAE. Groups VII-IX (SIEE treated), at the dose of 100, 200, and $400 \mathrm{mg} / \mathrm{kg} \mathrm{b.w}$ with $\mathrm{CCl}_{4}$ in olive oil (1:1) at dose 
of $0.5 \mathrm{~mL} / \mathrm{kg}$ b.w., respectively, received SIEE. In case of prophylactic test, vehicle doses, extracts, and silymarin were orally administered daily for 12 days; however, $\mathrm{CCl}_{4}$ was administered intraperitoneal (i.p.) on the alternative days in past 5 days, namely on $8^{\text {th }}, 10^{\text {th }}$, and $12^{\text {th }}$ days. In study cases based on curative effects, $\mathrm{CCl}_{4}$ was administered by i.p. on alternative days for the duration of the first 5 days, namely on $1^{\text {st }}, 3^{\text {rd }}$, and $5^{\text {th }}$ days although with the vehicle, extracts, and silymarin were administered orally for 12 days daily.

\section{Assessment of Hepatoprotective Activity by Barbiturate-induced Sleep Model}

It is used in both prophylactic and curative studies. On the $13^{\text {th }}$ day, all animals got pentobarbital sodium (PS) $(25 \mathrm{mg} / \mathrm{kg}$ b.w., i.p.) observed for their sleep. The time period between regain and loss of correcting reflex was noted as pentobarbitoneinduced sleeping time (PST) for every animal. ${ }^{[13,14]}$ Animals receiving various treatments euthanized on the $13^{\text {th }}$ day, and the blood samples are collected through retro-orbital penetrating method. Then, serum was removed by centrifugation at a speed of $1000 \mathrm{rpm}$ for time duration $10 \mathrm{~min}$ and examined for different biochemical factors including serum glutamic pyruvic transaminase (SGPT), serum glutamic oxaloacetic transaminase (SGOT), TB, and alkaline phosphatase (ALP) by the biochemical analyzer. The same practice was done for the determination of the levels of serum enzyme.

\section{Statistical Analysis}

Results of biochemical estimations were reported as mean \pm SEM. Total variation in a set of data was estimated by one-way analysis of variance (ANOVA), followed by Dunnett's test for determining statistical significance. The values $<0.05$ were considered as significant.

\section{RESULTS}

\section{Determination of Phytoconstituents}

The TPC in different extracts of SI was estimated through measure the blue color intensity formed at $\lambda_{\max } 765 \mathrm{~nm}$ whereas extracts TTC was estimated by deducting phenolics non-tannin from TPC. Their outcome was stated in comparison to gallic acid equivalent, $\mathrm{mg}$ of $\mathrm{GAE} / \mathrm{g}$ of extract (GAE) determined by regression equation $\mathrm{y}=0.0588 \mathrm{x}+$ 0.0025 and $r^{2}=0.9994$, where $\mathrm{x}$ is absorbance and $\mathrm{y}$ is GAE. Various SI extracts, moreover, exhibited different TTC, TPC, and TFC level [Figure 1].

\section{Estimation of Antioxidant Activity}

The antioxidant activities determined by different assay are presented in Figure 2.

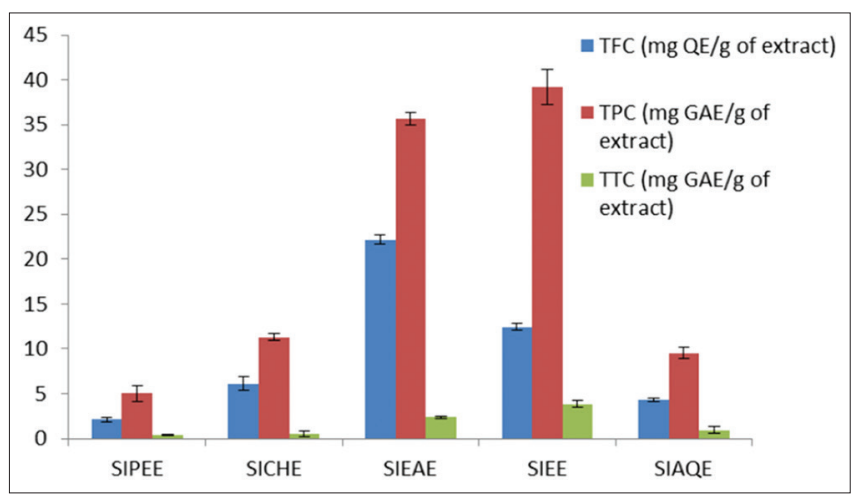

Figure 1: Quantity of total tannin content, total flavonoid content, and total phenolic content present in SI extracts

- Ferric reducing ability of plasma assay

In this study, the reducing ability of various extracts of SI was observed at various concentrations $(20-200 \mu \mathrm{g} / \mathrm{mL})$. The increase in absorbance further shows reducing the power of extract, as a major indicator of the antioxidant action potential. ${ }^{[15]}$ Different extracts of SI presented reducing power in the given order - Vitamin $\mathrm{C}>\mathrm{SIEE}$ $>$ SIEAE $>$ SICHE $>$ SIAQE $>$ SIPEE.

- DPPH radical scavenging assay

Various extracts presented different and scavenging activity dependent on dose in verified concentration limit. Beyond tested extracts, highest scavenging action detected with SIEE surveyed by SIEAE. $\mathrm{IC}_{50}$ of Vitamin $\mathrm{C}$ obtains as 7.1 $\pm 0.87 \mu \mathrm{g} / \mathrm{mL}$. The demand for scavenging action $\left(\mathrm{IC}_{50}\right)$ of Vitamin C and plant extracts originated as follows: $7.1 \mu \mathrm{g} /$ $\mathrm{mL}$ of Vitamin $\mathrm{C}>115.1 \mu \mathrm{g} / \mathrm{mL}$ of SIEE $>146.3 \mu \mathrm{g} / \mathrm{mL}$ of SIEAE $>208.2 \mu \mathrm{g} / \mathrm{mL}$ of SICHE $>263.2 \mu \mathrm{g} / \mathrm{mL}$ of SIAQE $>345.1 \mu \mathrm{g} / \mathrm{mL}$ of SIPEE. The SIEAE $\mathrm{IC}_{50}$ was found 20.61 times less than the Vitamin C. At the concentration $200 \mu \mathrm{g} / \mathrm{mL}$, the SIEAE and SIEE showed $48.5 \%$ and $50.4 \%$ DPPH scavenging property, respectively.

- $\mathrm{OH}^{\circ}$ scavenging assay

Various SI extracts demonstrate dose-dependent and varied scavenging action in tested range of concentration. Beyond the extracts tested, the highest scavenging property detected by SIEE afterward SIEAE. Vitamin $\mathrm{C}\left(\mathrm{IC}_{50}\right)$ was measured as $13.3 \pm 0.42 \mu \mathrm{g} / \mathrm{mL}$ and the direction of the scavenging effect $\left(\mathrm{IC}_{50}\right)$ of Vitamin $\mathrm{C}$ and extracts obtain as follows: $13.3 \mu \mathrm{g} / \mathrm{mL}$ of Vitamin $\mathrm{C}>103.5 \mu \mathrm{g} / \mathrm{mL}$ of SIEE $>168.1 \mu \mathrm{g} / \mathrm{mL}$ of SIEAE $>252.1 \mu \mathrm{g} / \mathrm{mL}$ of SICHE $>300.3 \mu \mathrm{g} / \mathrm{mL}$ of SIAQE $>413.1 \mu \mathrm{g} / \mathrm{mL}$ of SIPEE. SIEE $\mathrm{IC}_{50}$ found 12.64 times less than Vitamin C. At $200 \mu \mathrm{g} / \mathrm{mL}$ of concentration, the SIEAE and SIEE showed $35.5 \%$ and $57.1 \% \mathrm{OH}^{\circ}$ radical scavenging activity, respectively.

- $\mathrm{NO}^{\circ}$ radical scavenging activity

Various extracts elementpresenteddifferentand scavenging effect of dose-dependent in tested concentration variety. After verified extracts, highest scavenging action was 


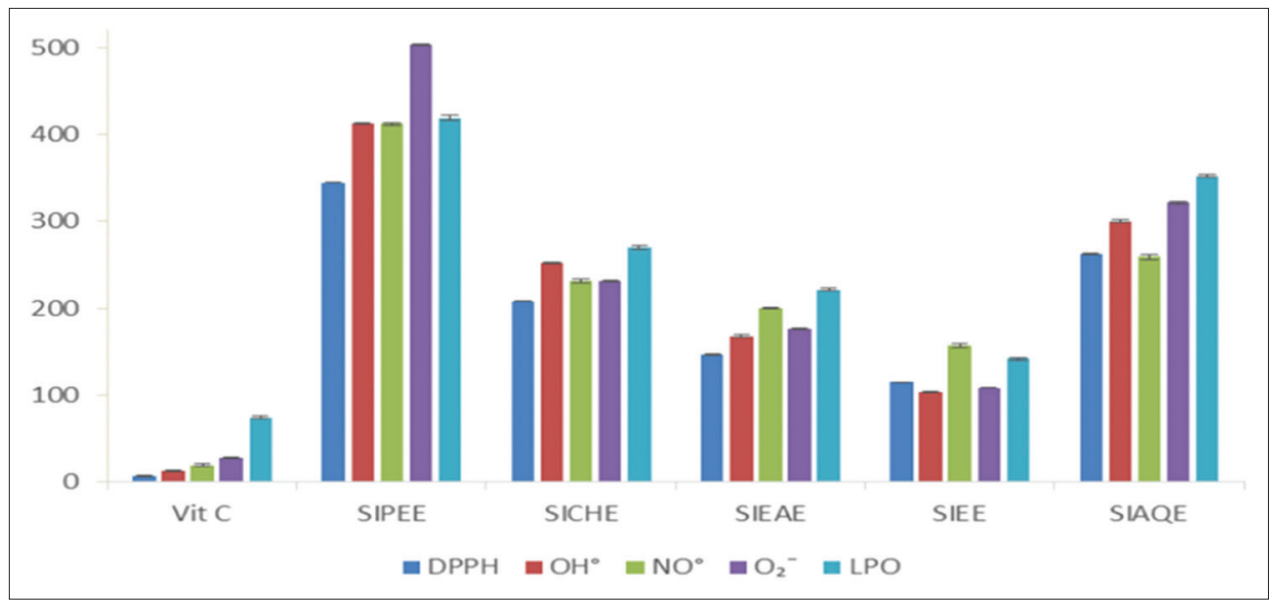

Figure 2: Antioxidant activity of SI extracts in terms of the $\mathrm{IC}_{50}$ value

perceived with SIEE afterward SIEAE. $\mathrm{IC}_{50}$ of Vitamin C was resulted as $19.6 \pm 1.72 \mu \mathrm{g} / \mathrm{mL}$. The way of scavenging activity $\left(\mathrm{IC}_{50}\right)$ of Vitamin $\mathrm{C}$ and extracts was found as follows: $19.6 \mu \mathrm{g} / \mathrm{mL}$ of Vitamin $\mathrm{C}>157.3 \mu \mathrm{g} / \mathrm{mL}$ of SIEE $>200.1 \mu \mathrm{g} / \mathrm{mL}$ of SIEAE $>231.1 \mu \mathrm{g} / \mathrm{mL}$ of SICHE $>259.3 \mu \mathrm{g} / \mathrm{mL}$ of SIAQE $>412.3 \mu \mathrm{g} / \mathrm{mL}$ of SIPEE. SIEE $\mathrm{IC}_{50}$ is obtained 10.21 times less as compared to Vitamin C. At $200 \mu \mathrm{g} / \mathrm{mL}$ of concentration, the SIEAE and SIEE presented $35.2 \%$ and $46.1 \% \mathrm{NO}^{\circ}$ radical scavenging property, respectively.

- Superoxide radical scavenging assay

Unalike extracts indicated a different and scavenging effect as dose-dependent in studied the concentration range. From tested extracts, highest scavenging action was detected with SIEE afterward SIEAE. $\mathrm{IC}_{50}$ as of Vitamin $C$ was obtained as $28.5 \pm 0.78$ and the manner of scavenging property $\left(\mathrm{IC}_{50}\right)$ of Vitamin $\mathrm{C}$ and extracts obtained as follows: $28.5 \pm 0.78 \mu \mathrm{g} / \mathrm{mL}$ of Vitamin C $>108.5 \mu \mathrm{g} / \mathrm{mL}$ of SIEE $>176.4 \mu \mathrm{g} / \mathrm{mL}$ of SIEAE $>231.3$ $\mu \mathrm{g} / \mathrm{mL}$ of SICHE $>321.7 \mu \mathrm{g} / \mathrm{mL}$ of SIAQE $>54.1 \mu \mathrm{g} / \mathrm{mL}$ of SIPEE. IC $_{50}$ of the SIEE found as 3.81 times less as compared to Vitamin C. At $200 \mu \mathrm{g} / \mathrm{mL}$ concentration, the SIEAE and SIEE presented $46.2 \%$ and $73.2 \%$ superoxide radical scavenging action, respectively.

- Inhibition of LPO assay

Several extracts presented different and scavenging action as dose-dependent in tried concentration limit. Beyond extracts tested, highest inhibition as of the LPO property was directed by SIEE afterward SIEAE. IC $_{50}$ of Vitamin C found as $74.6 \pm 0.98 \mu \mathrm{g} / \mathrm{mL}$ and the manner of scavenging action $\left(\mathrm{IC}_{50}\right)$ of Vitamin $\mathrm{C}$ and extracts obtain as follows: $74.6 \mu \mathrm{g} / \mathrm{mL}$ of Vitamin $\mathrm{C}>141.7 \mu \mathrm{g} / \mathrm{mL}$ of SIEE $>221.8$ $\mu \mathrm{g} / \mathrm{mL}$ of SIEAE $>270.5 \mu \mathrm{g} / \mathrm{mL}$ of SICHE $>352.5 \mu \mathrm{g} / \mathrm{mL}$ of SIAQE $>419.4 \mu \mathrm{g} / \mathrm{mL}$ of SIPEE. The $\mathrm{IC}_{50}$ of SIEE yields as 1.90 times less as that of Vitamin C. At concentration 150 $\mu \mathrm{g} / \mathrm{mL}$, the SIEAE and SIEE presented as $31.4 \%$ and $52.3 \%$, the inhibition of LPO scavenging action, respectively.

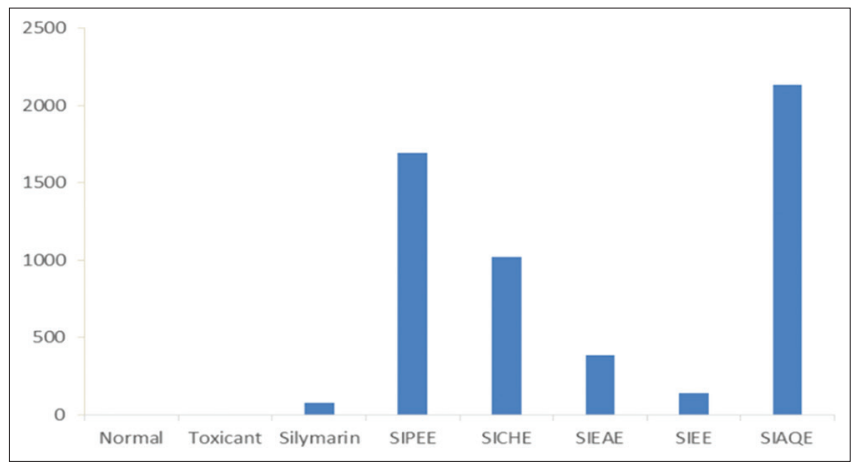

Figure 3: Effect of SI extracts on cell viability on human live hepatoma cells cell line against carbon tetrachloride-induced damage in terms of $\mathrm{IC}_{50}$

\section{Hepatoprotective Effects}

\section{In vitro hepatoprotective effect on HepG2 cell line against $\mathrm{CCl}_{4}$-induced damage}

Figure 3 indicates the results of in vitro protection effect of different SI extracts contrary to the $\mathrm{CCl}_{4}$-induced hepatic damage. Hepatocytes reacted by various SI extracts $(50-250 \mu \mathrm{g} / \mathrm{mL}, 100 \mu \mathrm{L})$ presented a modest to elevated protection action as manifest by reinstating the hepatocytes viability (23.7-69.3\%), but the silymarin standard drug $(50-250 \mu \mathrm{g} / \mathrm{mL}, 100 \mu \mathrm{L})$ presented great protection effect with renovating the cell viability (27.8-96.1\%). Among all SI extracts screened, extreme re-establishment was detected using SIEE (69.3\%) subsequently SIEE (42.9\%). $\mathrm{IC}_{50}$ of standard drug silymarin set up to be $80.3 \pm 0.51 \mu \mathrm{g} / \mathrm{mL}$. The manner of $\mathrm{IC}_{50}$ extracts and standard drug silymarin was obtained as follows: $80.3 \mu \mathrm{g} / \mathrm{mL}$ of silymarin $>143.8$ $\mu \mathrm{g} / \mathrm{mL}$ of SIEE $>383.7 \mu \mathrm{g} / \mathrm{mL}$ of SIEAE $>1021.1 \mu \mathrm{g} / \mathrm{mL}$ of SICHE $>1692.6 \mu \mathrm{g} / \mathrm{mL}$ of SIPEE $>2134.2 \mu \mathrm{g} / \mathrm{mL}$ of SIAQE. At $250 \mu \mathrm{g} / \mathrm{mL}$ concentration, the SIEAE showed as $42.9 \%$ and SIEE showed as $69.3 \%$ of cell sustainability, respectively. 


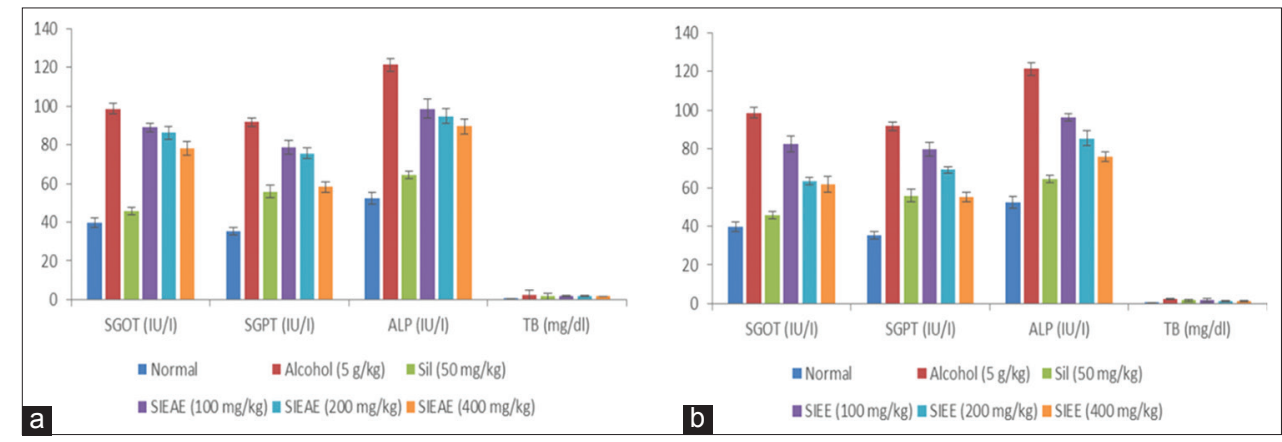

Figure 4: Protective effects of SI extracts on serum enzyme levels against alcohol-induced hepatic damage, (a) effect of SIEAE and (b) effect of SIEE. Every value presents the mean $\pm \operatorname{SEM}(n=6)$

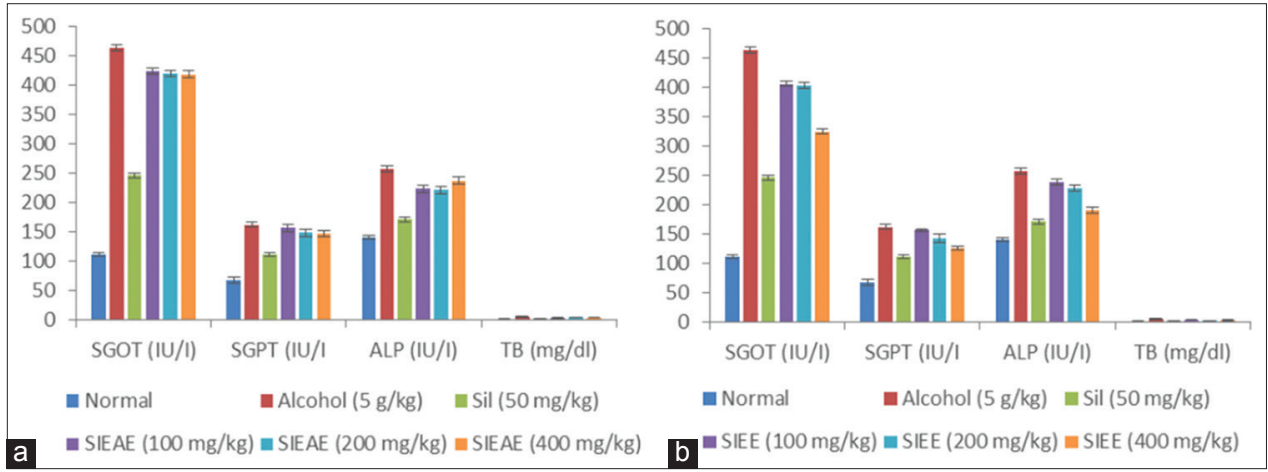

Figure 5: Curative effects of SI extracts on serum enzyme levels against alcohol-induced hepatic damage, (a) effect of SIEAE and (b) effect of SIEE. Every value presents the mean \pm SEM $(n=6)$

\section{Table 1: Effects of SI extract on PS-induced sleeping time in $\mathrm{CCl}_{4}$ intoxicated rats}

\begin{tabular}{|c|c|c|c|c|c|}
\hline \multirow[t]{2}{*}{ Groups } & \multirow[t]{2}{*}{ Dose (mg/kg, p.o.) } & \multicolumn{2}{|c|}{ Prophylactic effects } & \multicolumn{2}{|c|}{ Curative effects } \\
\hline & & $\begin{array}{c}\text { Recovery } \\
\text { time (Min) }\end{array}$ & $\%$ Recovery & $\begin{array}{l}\text { Recovery } \\
\text { time (Min) }\end{array}$ & $\%$ Recovery \\
\hline Group I (Normal control) & - & $62.4 \pm 3.72^{\star \star \star}$ & - & $62.4 \pm 3.72^{\star \star \star}$ & - \\
\hline Group II (Toxicant control) & CCl4 (0.5mL/kg), i.p. & $126.7 \pm 5.26$ & - & $158.3 \pm 5.92$ & - \\
\hline Group III (Silymarin treated) & 100 & $94.7 \pm 2.84^{\star \star}$ & 49.77 & $114.5 \pm 4.83^{\star \star \star}$ & 45.67 \\
\hline \multirow[t]{3}{*}{ Groups IV-VI (SIEAE treated) } & 100 & $116.8 \pm 5.93$ & 15.40 & $152.7 \pm 7.23$ & 5.84 \\
\hline & 200 & $114.5 \pm 6.37^{\star}$ & 18.97 & $141.7 \pm 5.93$ & 17.31 \\
\hline & 400 & $105.9 \pm 3.33^{*}$ & 32.35 & $132.6 \pm 6.91^{\star}$ & 26.80 \\
\hline \multirow[t]{3}{*}{ Groups VII-IX (SIEE treated) } & 100 & $118.6 \pm 5.12^{\star *}$ & 12.60 & $145.7 \pm 4.89$ & 13.14 \\
\hline & 200 & $118.4 \pm 5.23^{\star * *}$ & 12.91 & $131.5 \pm 4.92$ & 27.95 \\
\hline & 400 & $104.7 \pm 5.96^{\star \star}$ & 34.21 & $143.7 \pm 5.81^{\star \star}$ & 15.22 \\
\hline
\end{tabular}

PS: Pentobarbital sodium

\section{In vivo hepatoprotective effects}

- Acute toxicity studies

Certainly not any mortality and adverse variations were detected in animals, orally expected several SI extract up to body weight of $2000 \mathrm{mg} / \mathrm{kg}$. This shows that dose of $2000 \mathrm{mg} / \mathrm{kg}$ is the extreme harmless dose. Therefore, $1 / 20^{\text {th }}, 1 / 10^{\text {th }}$, and $1 / 5^{\text {th }}$ specifically body weight of 100,200 , and $400 \mathrm{mg} / \mathrm{kg}$, of which the greatest safe dosage was certain for testing in vivo hepatoprotective result.
- Direct prophylactic and curative effect

The rat hepatic damage produced by ethanol is considered by the high serum levels, namely, SGPT, SGOT, TB, and ALP in vivo level of antioxidant enzymes also histopathological variation, reproduce the strictness of hepatic injury. In this study, a significant rise in serum enzyme actions was perceived on the administration of ethanol illuminating toxic consequence on liver. The control group ethanol indicated a rise in the serum levels of SGPT (2.6 fold), TB (7.25 fold), ALP (2.4 fold), and SGOT (2.5 fold). In this group, the high levels were 
establish to be $91.6 \pm 2.39,2.32 \pm 0.43,121.3 \pm 3.44$, and $98.5 \pm 2.78$, respectively, against normal group which levels were $39.6 \pm 2.48,35.3 \pm 1.76,52.3 \pm 3.22$, and $0.32 \pm 0.15$, respectively [Figures 4 and 5].

\section{Indirect Method of Prophylactic and Curative Effect}

PS is a short-acting barbiturate, prompts the sleep and metabolized by microsomal drug metabolizing enzyme (MDME). Uptake of $\mathrm{CCl}_{4}$ inhibits the MDME in liver. Whichever substance $\mathrm{CCl}_{4}$ prevents the MDME is likely to extend $\mathrm{PB}$-induced sleeping duration. $\mathrm{CCl}_{4}$ given, that is, in curative and prophylactic study prevents MDME of cured rats. On the $13^{\text {th }}$ day uptake of PS ( $25 \mathrm{mg} / \mathrm{kg}$, i.p.) extends the PST prompted by PS in all the treated rats [Table 1]. PST by PS was in an arrangement with earlier findings. ${ }^{[13]}$

Every values presents the mean \pm SEM $(n=6),{ }^{*} P<0.05$, $* * P<0.01, * * * P<0.001$, respectively, as compared by toxicant control group $\mathrm{CCl}_{4}$ (one-way ANOVA followed by Dunnett's test). Percentage recovery is calculated as (value of $\mathrm{CCl}_{4}$ control - value of treatment)/(value of $\mathrm{CCl}_{4}$ control value of normal control) x 100 .

\section{DISCUSSION}

SIEE comprises triterpenoids, carbohydrate, alkaloids, flavonoids, glycosides, and sterols; SIEAE consists of tannins and flavonoids; SICHE consists of phytosterols and triterpenoids despite that SIAQE consists of glycoside, carbohydrate, and alkaloids. Amino acids and proteins were lacking in all extracts whereas fats and fixed oil were present only in the SIPEE of SI. Further SI extracts, namely SICHE, SIAQE, and SIPEE show a smaller amount of antioxidant action against standard Vitamin C. Additional, in vitro hepatoprotective assay, $\mathrm{CCl}_{4}$ visible $\mathrm{HepG} 2$ cell resulted as decreased in the viability of cell able to $20.4 \pm$ $0.81 \%$ against $99.5 \pm 0.34 \%$ of normal control group. SIEAE extract shows mild increase in cell viability $42.9 \pm 2.38 \%$ $\left(\mathrm{IC}_{50}=383.7 \pm 3.12\right)$ against toxicant control. In the present study, toxic effects caused by alcohol on liver cells which is characterized through the elevated serum levels; change in the level of tissue antioxidant enzymes as histopathological variations. Rats reacted from ethanol represented elevated level of enzymes as 2.0 fold of SGOT, 2.6 fold SGPT, 2.3 fold ALP, and 4.1 fold TB in serum than normal control. The rats treated by SIEAE showed the least variations contrast to alcohol.

Pre-treatment using SIEE extract $(100,200$, and $400 \mathrm{mg} / \mathrm{kg})$ presented vital $(P<0.001)$ prophylactic effects dependent on the dose as compared to $\mathrm{CCl}_{4}$-induced hepatic injury against standard silymarin. At dose of $400 \mathrm{mg} / \mathrm{kg}$, pretreatment using SIEE verified vital $(P<0.001)$ decline in increased level of serum enzyme in contrast to control group of $\mathrm{CCl}_{4}$ and presented protection percent of $52.54 \%, 53.32 \%$, $59.44 \%$, and 50.15\% against increased SGOT, SGPT, ALP, and TB, respectively. The pre-treatment using SIEE results as vital $(P<0.001)$ decrease in dose-dependent PST. At an equal dose $(400 \mathrm{mg} / \mathrm{kg})$, pre-treatment using SIEE presented $34.21 \%$ decline in PST against control group $\mathrm{CCl}_{4}$, however, pre-treatment by silymarin generates $49.77 \%$ deduction in the PST. The hepatic injury was considered by high serum enzymes of levels, namely SGPT, SGOT, ALP, and TB. The $\mathrm{CCl}_{4}$ inhibits the liver MDME, thus rise in PST-induced through PS. The $\mathrm{CCl}_{4}$ control group has shown a vital rise in SGPT (2.11 fold), SGOT (4.09 fold), ALP (1.83 fold), and TB (2.74 fold) against normal group.

\section{CONCLUSION}

Based on the present study, the plant extracts effectively used as curative and prophylactic/protective approaches in the circumstance of acute hepatic damage. The study indications connected to the hepatoprotective activity verified the efficacy of $S$. indicus in the management of the acute hepatic ailments and recognized the therapeutic activity in folk and traditional drugs. Additional studies required to enhance characterize the new phytoconstituents and their comprehensive process of action accountable for the hepatoprotective action of $S$. indicus.

\section{REFERENCES}

1. Kirtikar KR, Basu BD. Indian Medicinal Plants. $2^{\text {nd }}$ ed., Vol. 4. Dehradun: International Book Distributors; 1987. p. 2423-6.

2. Ambavade SD, Mhetre NA, Tate VD, Bodhankar SL. Pharmacological evaluation of the extracts of Sphaeranthus indicus flowers on anxiolytic activity in mice. Ind J Pharmacol 2006;38:254-9.

3. Olajuyigbe OO, Afolayan AJ. Phenolic content and antioxidant property of the bark extracts of Ziziphus mucronata willd. Subsp. Mucronata willd. BMC Complement Altern Med 2011;11:130.

4. Chouhan HS, Singh SK. Phytochemical analysis, antioxidant and anti-inflammatory activities of phyllanthus simplex. J Ethnopharmacol 2011;137:1337-44.

5. Sunil C, Ignacimuthu S. In vitro and in vivo antioxidant activity of Symplocos cochinchinensis S. Moore leaves containing phenolic compounds. Food Chem Toxicol 2011;49:1604-9.

6. Gul MZ, Ahmad F, Kondapi AK, Qureshi IA, Ghazi IA. Antioxidant and antiproliferative activities of Abrus precatorius leaf extracts-an in vitro study. BMC Complement Altern Med 2013;13:53.

7. Wang $\mathrm{H}$, Gao XD, Zhou GC, Cai L, Yao WB. In vitro and in vivo antioxidant activity of aqueous extract from Choerospondias axillaris fruit. Food Chem 2008;106:888-95. 
8. Shirwaikarkar A, Somashekar AP. Anti-inflammatory and free radical scavenging studies of Aristyolochia bracteolate lam. India J Pharm Sci 2003;65:67-9.

9. Shukla S, Mehta A, John J, Singh S, Mehta P, Vyas SP. Antioxidant activity and total phenolic content of ethanolic extract of Caesalpinia bonducella seeds. Food Chem Toxicol 2009;47:1848-51.

10. Singh N, Rajini PS. Free radical scavenging activity of an aqueous extract of potato peel. Food Chem 2004;85:611-6.

11. Yen GC, Hsieh CL. Antioxidant activity of extracts from du-zhong (Eucommia urmoides) towards various peroxidation models in vitro. J Agric Food Chem 1998;46:3952-7.

12. Organisation for Economic Co-operation and Development (OECD) Guideline No. 423. Guideline for
Testing of Chemicals: Acute Oral Toxicity-Acute Toxic Class Method; 2001.

13. Farida T, Salawu OA, Tijani AY, Ejiofor JI. Pharmacological evaluation of Ipomoea asarifolia (Desr.) against carbon tetrachloride-induced hepatotoxicity in rats. J Ethnopharmacol 2012;142:642-6.

14. Anand KK, Gupta VN, Rangari V, Singh B, Chandan BK. Structure and hepatoprotective activity of a biflavonoid from Canarium manii. Planta Med 1992;58:493-5.

15. Loganayaki N, Siddhuraju P, Manian S. Antioxidant activity and free radical scavenging capacity of phenolic extracts from Helicteres isora L. And Ceiba pentandra L. J Food Sci Technol 2013;50:687-95.

Source of Support: Nil. Conflict of Interest: None declared. 